\title{
A Comparative Study of The Students' Critical Reading Competency on High Order Thinking Items in A Junior High School
}

\section{N.K. Ratna Kusuma Rini1 ${ }^{*}$, D.K. Tantra², N.L.P. Eka Sulistia Dewi ${ }^{3}$}

${ }^{123}$ English Language Education, Post Graduate Program, Universitas Pendidikan Ganesha, Singaraja, Indonesia

A R T I C L E I N F O

Article history:

Received 10 August

z2020

Received in revised

Form 16 September

2020

Accepted 18 October

2020

Available online 01

November 2020

Keywords:

Critical Reading, Reading

Competency

\begin{abstract}
A B S T R A C T
This study aims to analyze and describe the students' reading competencies and comparing simultaneously the students reading competencies on high order thinking items across classes, text genres, and reading indicators. The design implemented was descriptive in order to answer the first research question and comparative research in order to answer the second research questions. The instrument used for data collection was reading competency test. The data were then analyzed descriptively and inferentially by implementing a parametric statistic, namely: central tendency measures; measures of dispersion; and simultaneous comparison. The present study was applied one-way ANOVA as the inferential analysis. The result showed, the significant value of one-way ANOVA on the students Reading Competency was 0.75 . The significant figure was higher than 0.05 . As a result, the students reading competency in high order thinking items was not significant. Therefore, the null hypothesis was accepted. It can be drawn a conclusion that the students reading competencies on high-order-thinking items across classes, text genres, and reading indicators are in below average.
\end{abstract}

\section{Introduction}

Reading is one part of literacy, which is structured as a process of using reading, writing, and spoken language to extract, build, integrate, and criticize meaning through interaction and is combined with multimodal texts in negotiations relating to social activities (Albeckay, 2014; Frankel et al., 2016; Wilson, 2016). They further state that in order to avoid misunderstanding in receiving information, then the students need to improve their skill in reading. The students can develop their mind which makes them smarter in solving problems through reading a text (Abdel Halim, 2011; Albeckay, 2014; Belet \& Dal, 2010).

Reading is very important in increasing human knowledge since it is a part of humans' daily life. Reading skills are very important for every individual, because this can foster their understanding of reading to avoid things that are hoaxes (Duran \& Yalçintaş, 2015; Harrison, 2004). In line with those statement, the importance of critical thinking in reading which is considered as the ability of students to analyze arguments, draw conclusions using reasoning, assess or evaluate, and make decisions or problem solving (Lai, 2011). Cognitive value of students is proven to increase with the empowerment of critical thinking skills, especially in daily learning (Cano \& Martinez, 1991).

Literacy and critical thinking do have a close relationship, therefore critical thinking based on HOTS (Higher Order Thinking Skills) is very important (Doležalová, 2015; Rogiers et al., 2020). HOTS have a very important role in building a literacy culture because it is in line with what has been mandated in the development of the 2013 curriculum. Reporting from one of the most prestigious programs employed to measure worldwide educational achievement that is Programmer for International Student Assessment (PISA) offered by Organization for Economic Cooperation and Development (OECD), which Indonesia has the lower grade in reading level (OECD, 2013).

In the Junior and Senior High Schools in Indonesia, reading is geared toward the attainment of competency. According to the 2013 Curriculum, competency is broadly determined as a set of attitude, knowledge, and skills in comprehending the texts structures and contents (Kemendikbud, 2013). Despite 
of the new scientific-oriented curriculum deployed since 2013, the EFL students' reading competency has not been attained satisfactorily as expected. Nor the refinement of reading strategies were endeavored since then.

Many EFL students possessed deficiencies in reading (Abdel Halim, 2011; Albeckay, 2014; Ningsih, 2016). Data have shown clearly, the students' reading scores were declining over the years since 2012 to 2018. When compared to other countries, Indonesia positioned lowest in the rank when they joined the Program for International Students Assessment (PISA) in three consecutive years, they are, 2012, 2015, and 2018.

In 2018, there were 79 countries participated in PISA (Pratiwi, 2019; Schleicher, 2018). As reported in PISA, the Indonesian students' reading scores still showed deficiencies. The students' reading scores, when compared to other countries, were ranked on 72 out of 79 countries. Moreover, their reading mean score dropped to 371 despite the new curriculum has been deployed for five years. The PISA's result proofed that the scientific approach was really a failure in developing the students' reading competency, especially in finishing up high-order-thinking items.

In the previous study, the students' reading competency at the beginning of the lecture was tested, it is the same as the present research but it is conducted for junior high school students who were in grade 7. In the previous research it was shown that many students were having lack understanding of reading competency at first, but then, after getting the course a lot of changes that occur. Students were found to be able to understand reading competency after receiving treatment in the form of courses at the beginning of lecture. In contrast to this research which focuses more on students' reading competency in understanding questions based on High Order Thinking Items. Even though the curriculum has changed, in reality there are still many students in Indonesia are weak in literacy (Abdel Halim, 2011; Delgadova, 2015; Din, 2020).

The present research is endeavored to describe and compare the students' reading competency, especially on high-order-thinking items in the SMPN 10 Denpasar. The reading competency was measured using high-order-thinking items beyond the cognitive domain levels of $\mathrm{C} 1, \mathrm{C} 2$, and $\mathrm{C} 3$; the affective domain levels of A1 and A2; psychomotor domain levels of P1 and P2. affective domain of levels A3 and A4; psychomotor domain of levels P3, P4, and P5. The text genres studied were of two types, namely: descriptive texts about a person, an animal, a place, a procedure, and recount texts about a personal experience and an accident. The text indicators measured consisted of four aspects, namely the main idea, the specific ideas, the textual references, and the word meanings in both descriptive and recount text.

\section{Methods}

Research design can be described as a plan and procedure that includes the decision of the council to the assumptions detailed method of data collection and analysis (Cresswell, 2012). Therefore, it is very important for researchers to determine the design in a study as a plan to be implemented in relation to research objectives. The design implemented was that of a descriptive and comparative research. Firstly, data were analyzed descriptively and inferentially by implementing a parametric statistics, namely: 1) central tendency measures, 2) measures of dispersion, and 2) simultaneous comparisons across classes, text genres, and reading indicators, and 3) post-hoc multiple comparisons, and 4) trend analysis (Gall \& Borg, 2007; Glass \& Hopkins, 1984; Hinkle et al., 1979).

Sugiyono (2014) Population in a study is a group consisting of objects and subjects that have qualities as well as certain characteristics that will ultimately be determined by researchers to then draw a conclusion (Sugiyono, 2014). Population as a larger group that researchers want to generalize which includes all class members of certain people, events, or objects (Ary et al., 2010). The research population in this study were the seventh-grade students in SMPN 10 Denpasar in the Academic Year 2019/2020. There were four intact classes with 132 students altogether in the population. Eight intact classes with 260 students altogether in the population. Four classes were sampled in order to exceed to $n=30$. This was also done to gain normal sample distribution. The sample size consisted of 101 students altogether.

Samples are parts of the population that are the object or subject of research. The sample technique used is cluster random sampling. This technique is a combination of cluster sampling and random sampling techniques. This sampling technique is a way of taking classes randomly from classes that already exist as a population. This random sampling cluster was chosen because the sample taken for the study was a group of students that had been formed without the intervention of the researcher, meaning that the researcher used classes that had been formed at the school. As long as long as these individuals have the same characteristics that have to do with research variables, then these individuals constitute a group or cluster (Furchan, 1990). The way to take random class samples in this study was by simple lottery. 
The instrument used to collect data was that of a Reading Competency Test. Reading competency is a set of attitude, knowledge, and skills. There are four indicators of reading competency, namely: the main idea that is a complete simple sentence which illustrates the general idea of a text; specific ideas are detailed pieces of information containing in the paragraphs; textual references are pronouns in reference to specific nouns in the descriptive and recount texts; and word meanings are the implicational/psychological words/phrases' meanings (Latifa, 2018).

\section{Result and Discussion}

\section{Results}

Descriptive Statistics

After the instrument was administered procedurally, the intended data gathered and analyzed systematically. The students were tested on descriptive and recount reading texts through 1) administering the test items to different classes simultaneously, 2) the students worked independently on the test items for 60 minutes, 3) they completed the test and submitted to the researcher in due time. As there are two research questions proposed in this study, the discussion focuses on finding those two research questions. Firstly, discussion is about the students' reading competencies on high-order-thinking items across classes, text genres, and reading indicators. Then, the second discussion focuses on the significant differences in the students' reading competencies on high-order-thinking items across classes, text genres, and reading indicators. Data were analyzed, firstly descriptively, and then, inferentially by implementing parametric statistics, namely: 1) central tendency measures, 2) measures of dispersion, and 2) simultaneous comparisons across classes, text genres, and reading indicators. The data of the present study were collected by administering reading competency test in the form of multiple choice with 132 samples altogether.

Table 1. Descriptive Statistics of the Students' Reading Competency in General

\begin{tabular}{lc}
\hline \multicolumn{1}{c}{ Statistics } & Descriptive Values \\
\hline Arithmetic Mean & 48.73 \\
Range & 16 \\
Standard Deviation & 3.88 \\
Variance & 15.10 \\
Standard Error & 0.33 \\
\hline
\end{tabular}

Table 1 shows the students of SMPN 10 Denpasar reading competency mean score $=48,73$ out of the total reading competency score $=100$. Categorically, the students' reading competency in high-orderthinking items are categorized as moderate (Mean \pm 1 Standard Deviation). The students' range score discloses another interesting fact about the students' reading competency in SMPN 10 Denpasar. The range between the highest-scored and the lowest-scored students on the reading competency is equal to 16.00. The range between high and low reading competency is quite wide (range $=16$ ). It means the variability between the high and low reading competency of the students is wide enough (standard deviation= 3.88; variance $=15.10$ ). The students' reading competency are categorized as moderate on both the descriptive texts about a person, an animal, a place, a procedure, and recount texts about a personal experience as well as an accident in the range scores $=16$.

Further analysis is conducted across classes. There are four intact classes in which the students' reading competency on high-order-thinking items were measured. The results are shown in Table 2.

Table 2. Descriptive Statistics of the Students' Reading Competency Across Classes

\begin{tabular}{clc}
\hline Class & \multicolumn{1}{c}{ Statistics } & Descriptive Values \\
\hline \multicolumn{4}{c}{ I } & Arithmetic Mean & 49.00 \\
& Range & 12 \\
& Standard Deviation & 2.87 \\
& Variance & 8.25 \\
& Standard Error & 0.50 \\
& Arithmetic Mean & 48.47 \\
& Range & 12 \\
& Standard Deviation & 3.37 \\
\hline
\end{tabular}




\begin{tabular}{|c|c|c|}
\hline Class & Statistics & Descriptive Values \\
\hline \multirow{7}{*}{ III } & Variance & 11.4 \\
\hline & Standard Error & 0.58 \\
\hline & Arithmetic Mean & 48.59 \\
\hline & Range & 16 \\
\hline & Standard Deviation & 4.73 \\
\hline & Variance & 22.4 \\
\hline & Standard Error & 0.81 \\
\hline \multirow{5}{*}{ IV } & Arithmetic Mean & 48.88 \\
\hline & Range & 16 \\
\hline & Standard Deviation & 4.40 \\
\hline & Variance & 19.3 \\
\hline & Standard Error & 0.78 \\
\hline
\end{tabular}

Table 2 shows the students' reading competency averages across classes. The mean scores of reading competency show different result in each class. The differences of the mean scores across classes differ at minimum points. The mean scores of reading competency in class I $=49.00$, class II $=48.47$, class $\mathrm{III}=48.59$, and class IV $=48.88$. The mean differences are quite similar to one and another. However, categorically the students' reading competency across classes could be said in low level.

The students' range scores disclose another interesting fact about the students' reading competency in SMPN 10 Denpasar. The variabilities of the reading competency scores vary across classes (variance in class I $=8,25$ ); variance in class II $=11,4$; variance in class III $=22.4$; variance in class IV=19.3).

When the students' reading competency on higher-order-thinking items is analyzed based on the reading text types, the results are clearly shown in Table 3.

Table 3. Descriptive Statistics of the Students' Reading Competency in Descriptive Text

\begin{tabular}{lccccc}
\hline \multirow{2}{*}{\multicolumn{1}{c}{ Statistics }} & \multicolumn{4}{c}{ Descriptive Values and Classes } \\
\cline { 2 - 6 } & I & II & III & IV & Average \\
\hline Arithmetic Mean & 25,25 & 24,71 & 25,18 & 25,75 & 25,21 \\
Range & 24 & 28 & 20 & 24 & 32 \\
Standard Deviation & 5,51 & 7,40 & 4,04 & 6,17 & 5,84 \\
Variance & 30,38 & 54,8 & 16,02 & 38,1 & 34,1 \\
Standard Error & 0,97 & 1,27 & 0,68 & 1,1 & 0,5 \\
\hline
\end{tabular}

The arithmetic means of the students' reading competency could be ordered based on text types across classes as follows. First, the students' reading competency is the highest in class IV on the descriptive text (mean $=25.75)$, class II is the second highest (mean $=25.25)$, class III is the third highest (mean $=25.18)$, and the lowest is in class II (mean $=24,71$ ) on the descriptive text type.

Table 4. Descriptive Statistics of the Students' Reading Competency in Recount Text

\begin{tabular}{lccccc}
\hline \multirow{2}{*}{\multicolumn{1}{c}{ Statistics }} & \multicolumn{5}{c}{ Descriptive Values and Classes } \\
\cline { 2 - 5 } & I & II & III & IV & Average \\
\hline Arithmetic Mean & 23,75 & 23,76 & 23,41 & 23,13 & 23,52 \\
Range & 20 & 24 & 16 & 28 & 28 \\
Standard Deviation & 5,17 & 7,09 & 4,3 & 6,4 & 5,78 \\
Variance & 26,78 & 50,37 & 18,55 & 41,0 & 33,47 \\
Standard Error & 0,91 & 1,21 & 0,73 & 1,13 & 0,50 \\
\hline
\end{tabular}

The arithmetic means of the students' reading competency could be ordered based on text types across classes as follows. First, the students' reading competency is the highest in class II on the recount text $($ mean $=23.76)$, class $\mathrm{I}$ is the second highest (mean $=23.75)$, class III is the third highest (mean = 23.41), and the lowest is in class IV (mean $=23.13$ ) on the recount text type.

When the students' reading competency on higher-order-thinking items is analyzed based on the reading competency indicators, the results are clearly shown in Table 5. 
Table 5. Descriptive Statistics of the Students' Reading Competency Across Indicators

\begin{tabular}{ccccccc}
\hline \multirow{2}{*}{ Indicators } & \multirow{2}{*}{ Statistics } & \multicolumn{4}{c}{ Descriptive Values and Classes } \\
\cline { 3 - 6 } & & I & II & III & IV & Average \\
\hline Main Idea & Arithmetic Mean & 12,38 & 11,65 & 11,53 & 12,13 & 11,91 \\
Specific Ideas & Arithmetic Mean & 11,50 & 12,24 & 11,65 & 11,75 & 11,79 \\
Textual Reference & Arithmetic Mean & 11,88 & 12,35 & 12,12 & 11,75 & 12,03 \\
Word/Phrase & Arithmetic Mean & 13,25 & 12,24 & 13,29 & 13,25 & 13,00 \\
Meaning & & & & & \\
& & & & & & \\
& Standard Deviation & 2,87 & 3,37 & 4,73 & & 3,87 \\
\hline
\end{tabular}

Table 5 shows the specific students' reading competency based on the reading competency's indicators, namely 1) main idea or a complete simple sentence which illustrate the general idea of a text, 2) specific ideas or specific pieces of information containing in the paragraph, and 3) textual reference or pronouns in reference to specific nouns in the text, and 4) word meaning or denotative meaning. The reading indicators' means are calculated as $11.91,11.79,12.03$, and 13.00 respectively.

The main idea or a complete simple sentence which illustrate the general idea of a text could be concluded as moderate or equal to 11.91 (mean \pm 1 standard deviation). While the specific ideas or specific pieces of information containing in the paragraph could be concluded as moderate or equal 11.79 (mean \pm 1 standard deviation). Furthermore, the textual reference or pronouns in reference to specific nouns in the text could be concluded as moderate or equal to 12.03 (mean \pm 1 standard deviation). And finally, the word meaning or denotative meaning can be concluded as moderate or equal to 13.00 (mean \pm 1 standard deviation).

When the arithmetic means of the students' reading competency are ordered from highest to lowest based on its indicators as shown in Table 5, the order is as follows. The students' reading competency of high-order-items on word phrase is the highest. It means that the students have the ability to work on word phrase/meaning of high-order-items, followed with textual references, main ideas, and specific ideas. The largest variability in terms of reading competency indicators exists in the class III, followed by class IV, class II, and class I.

\section{Simultaneous Comparison of Reading Competency}

The result of descriptive analysis showed that the mean score of the samples were as follows: $49.00,48.47,48.59$, and 48.88 . These results indicated that the mean score of descriptive paragraphs have minimum points at the difference. Since the mean score of four classes were different, to prove whether the students reading competency in high order items was significant or not, one-way ANOVA analysis was computed by using SPSS 16.0 version. Based on the output of SPSS 16.0 program for windows, the result of the hypothesis testing through one-way ANOVA could be briefly presented in Table 6 .

Table 6. Summary Anova of Reading Competency

\begin{tabular}{cccccc}
\hline Source & SS & Df & MS & F & Sig. \\
Between & 5.98 & 3 & 1.99 & 0.12 & 0.94 \\
Within & 1972.2 & 128 & 15.40 & & \\
\hline Total & 1978.18 & 131 & & & \\
\hline
\end{tabular}

Table 6 showed that the significant value of one-way ANOVA on the students Reading Competency was 0.94 . The significant figure was higher than 0.05 . As a result, the students reading competency in high order thinking items was not significant. Therefore, the null hypothesis was accepted. It can be drawn a conclusion that the students reading competencies on high-order-thinking items across classes, text genres, and reading indicators in SMPN 10 Denpasar are below average. Since the students reading competency in high order thinking items was found statistically insignificant, Post-hoc Multiple comparison using Tukey's HSD Test could not be continuously computed.

\section{Discussion}

This present research was intended to investigate the students' reading competency on high order items in the junior high school. In addition, it was intended to investigate the significant differences of the students reading competency on high order items in the junior high school. The data of the present 
research were mainly gathered through administering research instrument which was reading competency test in the form of multiple choice. The instrument was administered to the samples under investigation of reading competency.

In the previous study, the students' reading competency at the beginning of the lecture was tested, it is the same as the present research but it is conducted for junior high school students who were in grade 7. In the previous research it was shown that many students were having lack understanding of reading competency at first, but then, after getting the course a lot of changes that occur. Students were found to be able to understand reading competency after receiving treatment in the form of courses at the beginning of lecture. In contrast to this research which focuses more on students' reading competency in understanding questions based on High Order Thinking Items. Even though the curriculum has changed, in reality there are still many students in Indonesia are weak in literacy (Abdel Halim, 2011; Delgadova, 2015; Din, 2020).

The present research is endeavored to describe and compare the students' reading competency, especially on high-order-thinking items in the SMPN 10 Denpasar. The reading competency was measured using high-order-thinking items beyond the cognitive domain levels of $\mathrm{C} 1, \mathrm{C} 2$, and $\mathrm{C} 3$; the affective domain levels of A1 and A2; psychomotor domain levels of P1 and P2. affective domain of levels A3 and A4; psychomotor domain of levels P3, P4, and P5. The text genres studied were of two types, namely: descriptive texts about a person, an animal, a place, a procedure, and recount texts about a personal experience and an accident. The text indicators measured consisted of four aspects, namely the main idea, the specific ideas, the textual references, and the word meanings in both descriptive and recount text.

Based on descriptive and inferential analysis, the result clearly pointed out that the students' reading competency on high order items categorized as poor. In addition, the result of the statistical analysis by using one-way ANOVA showed that there was no significant difference in the students reading competency across class, text genres, and reading indicators.

In line with the result of the present research, there are some possible ways to help the students to increase their achievement in reading competency. First, poor reading competency implies the teacher should assist the students to expose themselves and to practice as many as possible (Karadağ, 2014; Kim \& Hannafin, 2011). The more the students practice in the teaching learning process of reading; the better the result of their reading will be. Second, poor reading competency implies the teachers should train intensively and extensively in reading process in order the students have the ability in determining the main idea, specific idea, textual reference, and word or phrases meaning of both descriptive and recount texts (Akın et al., 2015; Din, 2020; Hashimoto et al., 2019; Wilson, 2016).

\section{Conclusion}

The conclusion of this present research can be briefly described. Based on the descriptive analysis, the students' reading competency on high order items in SMPN 10 Denpasar was categorized as poor. As a result, the students reading competency in high order thinking items was not significant. Therefore, the null hypothesis was accepted. It can be concluded that there was no statistically significant different of the students reading competency on high order items in SMPN 10 Denpasar.

\section{References}

Abdel Halim, S. M. (2011). Improving EFL majors' critical reading skills and political awareness: A proposed translation program. International Journal of Educational Research, 50(5-6), 336-348. https://doi.org/10.1016/j.ijer.2011.11.003

Akın, F., Koray, Ö., \& Tavukçu, K. (2015). How Effective is Critical Reading in the Understanding of Scientific Texts? Procedia - Social and Behavioral Sciences, 174, 2444-2451. https://doi.org/10.1016/j.sbspro.2015.01.915

Albeckay, E. M. (2014). Developing Reading Skills through Critical Reading Programme amongst Undergraduate EFL Students in Libya. Procedia - Social and Behavioral Sciences, 123, 175-181. https://doi.org/10.1016/j.sbspro.2014.01.1412

Ary, D., C., J. L., Sorensen, C., \& Razavieh, A. (2010). Introduction to Research in Education (English). Nelson Education, Ltd.

Belet, Ș. D., \& Dal, S. (2010). The use of storytelling to develop the primary school student's critical reading skill: The primary education pre-service teacher's opinions. Procedia - Social and Behavioral Sciences, 9, 1830-1834. https://doi.org/10.1016/j.sbspro.2010.12.409

Cano, J., \& Martinez, C. (1991). The relationship between cognitive performance and critical thinking 
abilities among selected agricultural education students. Journal of Agricultural Education, 32(1), 24-29. http://pubs.aged.tamu.edu/jae/pdf/vol32/32-0124.pdf

Cresswell, J. W. (2012). Educational Research. Pearson.

Delgadova, E. (2015). Reading Literacy as One of the Most Significant Academic Competencies for the University Students. Procedia - Social and Behavioral Sciences, 178(November 2014), 48-53. https://doi.org/10.1016/j.sbspro.2015.03.145

Din, M. (2020). Evaluating university students' critical thinking ability as reflected in their critical reading skill: A study at bachelor level in Pakistan. Thinking Skills and Creativity, 35(January), 100627. https://doi.org/10.1016/j.tsc.2020.100627

Doležalová, J. (2015). Competencies of Teachers and Student Teachers for the Development of Reading Literacy. Procedia - Social and Behavioral Sciences, 171, 519-525. https://doi.org/10.1016/j.sbspro.2015.01.156

Duran, E., \& Yalçintaş, E. (2015). Review of the Critical Reading Education in the Primary Schools1. Procedia - Social and Behavioral Sciences, 174, 1560-1566. https://doi.org/10.1016/j.sbspro.2015.01.788

Frankel, K. K., Becker, B. L., Rowe, M. W., \& Pearson, P. D. (2016). From "what is reading?" to what is literacy? Journal of Education, 196(3), 7-17. https://doi.org/10.1177/002205741619600303

Furchan, A. (1990). Pengantar penelitian Dalam Pendidikan. Usaha Nasional.

Gall, M. D., \& Borg, W. R. (2007). Educational Research: An introduction. Longman.

Glass, G., \& Hopkins, D. (1984). Statistical methods in Education and Psychology. Prentice-Hall Inc.

Harrison, C. (2004). Understanding Reading Development. Sage Publications.

Hashimoto, T., Hayashi, Y., \& Seta, K. (2019). Metacognitive inference activity support by visualizing eyemovement graph during critical reading. Procedia Computer Science, 159, 1995-2004. https://doi.org/10.1016/j.procs.2019.09.372

Hinkle, D. E., Wiersma, W., \& Jurs, S. G. (1979). Applied Statistics for the Behavioral Sciences (1st ed.). Houghton Mifflin Company.

Karadağ, R. (2014). Primary School Teacher Candidates' Views towards Critical Reading Skills and Perceptions of their Competence. Procedia - Social and Behavioral Sciences, 152, 889-896. https://doi.org/10.1016/j.sbspro.2014.09.339

Kemendikbud. (2013). Kerangka Dasar Kurikulum 2013. Kementerian Pendidikan dan Kebudayaan.

Kim, M. C., \& Hannafin, M. J. (2011). Scaffolding Problem Solving in Technology-enhanced Learning Environments (TELEs): Bridging Research and Theory with Practice. Computers and Education, 56(2), 403-417. https://doi.org/10.1016/j.compedu.2010.08.024

Lai, E. R. (2011). Critical thinking: A literature review. Pearson's Research Reports, 6(1), 40-41. http://images.pearsonassessments.com/images/tmrs/CriticalThinkingReviewFINAL.pdf.

Latifa, N. (2018). Teaching Narrative Text by Using Preview, Question, Read, State, and Test (PQRST) Technique. English Education Journal (EEJ), 9(2), 243-260. https://repository.arraniry.ac.id/id/eprint/5351/

Ningsih, S. (2016). Guided Writing to Improve the Students' Writing Ability of Junior High School Students. EFL Journal, 1(2), 129-140.

OECD. (2013). PISA 2012 Assessment and Analytical Framework: Mathematics, Reading, Science, Problem Solving and Financial Literacy. OECD Publishing.

Pratiwi, I. (2019). Efek Program Pisa Terhadap Kurikulum Di Indonesia. Jurnal Pendidikan Dan Kebudayaan, 4(1), 51-71. https://doi.org/10.24832/jpnk.V4i1.115

Rogiers, A., Van Keer, H., \& Merchie, E. (2020). The profile of the skilled reader: An investigation into the role of reading enjoyment and student characteristics. International Journal of Educational Research, 99(1). https://doi.org/10.1016/j.ijer.2019.101512

Schleicher, A. (2018). PISA 2018 Insight and Interpretation. Organization for Economic Co-operation and Development.

Sugiyono. (2014). Metode Penelitian Pendidikan Pendekatan Kuantitatif, Kualitatif, dan R\&D. Alfabeta.

Wilson, K. (2016). Critical reading, critical thinking: Delicate scaffolding in English for Academic Purposes (EAP). Thinking Skills and Creativity, 22, 256-265. https://doi.org/10.1016/j.tsc.2016.10.002 